\title{
Wolbachia infection associated with all-female broods in Hypolimnas bolina (Lepidoptera: Nymphalidae): evidence for horizontal transmission of a butterfly male killer
}

\author{
EA Dyson ${ }^{1}$, MK Kamath ${ }^{2}$ and GDD Hurst ${ }^{1}$ \\ ${ }^{1}$ Department of Biology, University College London, 4 Stephenson Way, London NW1 2HE, UK; ${ }^{2}$ Department of Forestry, Ministry \\ of Agriculture Fisheries and Forests, PO Box 2218 Government Buildings, Suva, Fiji Islands
}

Inherited bacteria that kill male hosts during embryogenesis infect a wide range of insect species. In order to ascertain if there are patterns to host infection, with particular male killing bacteria specialising on particular taxa, we investigated the male killing trait in the butterfly Hypolimnas bolina. All-female broods were first reported in this species in the 1920s. Investigation of this system in the Fiji Islands revealed the causal agent of sex ratio distortion in $\mathrm{H}$. bolina to be a male killing Wolbachia bacterium. This bacterium is identical in wsp and fts $Z$ sequence to a male killer in the butterfly Acraea encedon in Tanzania, suggesting it has moved between host species, yet retained its phenotype. The prevalence of the Wolbachia was calculated for three different island groups of Fiji, and found to vary significantly across the country. Antibiotics failed to cure either the male killing trait or the Wolbachia infection. The implications of these results are discussed.

Heredity (2002) 88, 166-171. DOI: 10.1038/sj/hdy/6800021

Keywords: Hypolimnas bolina; Wolbachia; male killing; Lepidoptera

\section{Introduction}

Inherited microorganisms are carried by more than onefifth of all insects (Werren et al, 1995). These bacteria and protists typically inhabit host cell cytoplasm and show maternal transmission. As their fitness in males is zero, selection favours strains of these microbes that produce a female bias to their host's sex ratio. Three different forms of sex ratio manipulation have been recognised: parthenogenesis induction, feminisation and embryonic male killing (Stouthamer et al, 2001). Of these a single bacterium, Wolbachia, is the only documented causal agent of parthenogenesis induction (Stouthamer, 1997). Feminisation is also associated with a single bacterium, again Wolbachia, as well as a range of protists (Rigaud, 1997). Embryonic male killers, in contrast, are much more diverse, deriving from five different bacterial clades separated by 2000 million years (Hurst et al, 1997). The lineages are: members of the genera Rickettsia and Spiroplasma, strains of Wolbachia pipientis, the gamma proteobacterium Arsenophonus nasoniae, and un-named strains from the Bacteroides - Flavobacteria division. To date, the Rickettsia and Flavobacteria solely infect beetles (Werren et al, 1994; Hurst et al, 1999a). Male killing A. nasoniae have only been recorded from the wasp Nasonia vitripennis (Werren et al, 1986). Wolbachia and spiroplasmas show much more host diversity. Five Wolbachia

Correspondence: EA Dyson, Department of Biology, University College London, 4 Stephenson Way, London NW1 2HE, UK.

E-mail:e.dyson@ucl.ac.uk

Received and accepted 22 May 2001 and three Spiroplasma male killers have been found within the insect orders Coleoptera, Diptera and Lepidoptera (Williamson and Poulson, 1979; Hurst et al, 1999b, c, 2000; Fialho and Stevens, 2000; Jiggins et al, 2000a, b).

Clearly some male killers are present in many different host groups. What is unclear, as yet, is whether some strains are restricted to particular host taxa. Restrictions might arise following specialisation on a particular host sex determination system: Wolbachia and spiroplasmas maybe the only male killing clades that can cross this boundary. Additionally, the relative incidence of these two genera, that can infect different host taxa, is unknown.

In order to study these patterns of host infection, we need to establish two factors: which male killers affect which taxa, and how many independent evolutions of male killing there are within each clade. An example of the latter is found within the clade Wolbachia; the male killer infecting Drosophila bifasciata is in the A sub-group, the other male killing Wolbachia are all members of the B sub-group (Hurst et al, 1999c, 2000), representing different evolutions of male killing. Similarly, there are at least two evolutions of male killing in the spiroplasmas (Schulenburg et al, 2000).

To resolve the above controversies requires systematic identification of a wider range of male killing agents. With this in mind, one of the oldest recorded cases of sex ratio distortion in an arthropod group, that of Hypolimnas bolina was re-examined.

In the early 1920s, HW Simmonds bred Hypolimnas bolina in the Fiji Islands, discovering the occurrence of all- 
female broods in this species. (Poulton, 1923, 1927, 1928; Simmonds, 1926). He reported that the 'all-female' trait was passed from mother to daughter, and was not due to parthenogenesis. Some 50 years later, Clarke and Sheppard (1975a) studied the genetics of the female wing polymorphism in this species, collecting and breeding butterflies from all over the Indo-Pacific. During their course of study, they recorded all-female broods in matrilines from Borneo, Sri Lanka and Hong Kong, reinforcing Simmonds' findings that the trait was passed through the female line. Cytological sexing of larvae and embryos indicated that the deficiency of males was due to their very high mortality in the pre-adult stage (Clarke et al, 1975b). Despite obtaining negative results when testing infected females for viral particles and spirochaetes, they suggested a cytoplasmic factor to be the cause of the observed sex ratio distortion. Clarke et al carried out a re-survey of H. bolina in Fiji in 1983. They demonstrated, by breeding experiments, the persistence of the phenomenon some 150 generations after it was originally recorded (Clarke et al, 1983) concluding that, 'no entirely satisfactory explanation has yet been given for the persistence of all-female broods'. In this paper, $H$. bolina in Fiji is re-examined and the causal agent of all-female broods identified.

\section{Methods}

Identification of male-killing lines

In July and August 1999, adult Hypolimnas bolina samples were collected from Suva and Nadi on the main Island of Viti Levu, Fiji. Butterflies were taken to Colo-I-Suva (eastern coast), caged, and the females encouraged to oviposit on a host plant, Ipomoea batatus (Vane-Wright et al, 1977). Adults were provided with 'false flowers' containing 0.4 M sugar solution on which to feed. Eggs laid in the laboratory were removed from the plant and each clutch stored in a Petri dish. The total number of eggs laid, number of eggs that hatched, and numbers of grey and yellow unhatched eggs were recorded in all cases. Each clutch was coded according to matriline.

An F1 generation was reared, larvae being fed on an excess of $I$. batatus leaves. Caterpillars were initially reared in Petri dishes, and transferred to large plastic pots after the second larval moult. No more than 10 larvae were reared per pot to avoid overcrowding. Sex ratio was recorded on emergence.

Adults from the F1 generation were mated in an $8 \mathrm{~m}^{3}$ outdoor flying cage. Outbreeding was ensured by only allowing interaction between unrelated F1 males and females. The F2 generation was reared from each matriline following the methods previously outlined.

\section{Association of Wolbachia with the all-female trait}

DNA was extracted from the ovaries of female butterflies and prepared for PCR analysis using the Qiagen DNA preparation kit, following the manufacturer's protocol. PCR, using primers wsp81f (5'-TGG TCC AAT AAG TGA TGA AGA AAC) and wsp691r (5'-AAA AAT TAA ACG CTA CTC CA-3') that amplify the bacterium's wsp gene (Zhou et al, 1998), was used to assay for the presence of Wolbachia. All females that had been bred in the laboratory, and their progeny, were tested. Specimens that gave negative results with ws p primers were tested to check the DNA extractions had been successful using PCR with two oligonucleotide primers for the mitochondrial $\mathrm{CO} 1$ block (Brunton and Hurst, 1998) (5'-GGA TCA CCT GAT ATA GCA TTC CC-3') and (5'CCG GTA AAA TTA AAA TAT AAA CTT C-3'). If DNA was present (positive result with CO 1) samples were retested for Wolbachia presence using wsp primers, as indicated above. If there was no DNA (negative result with CO 1) the DNA sample was re-prepared, and the process repeated.

\section{Sequence analysis and phylogenetic position}

Bacterial ftsZ and wsp DNA was amplified from two individual infected female $H$. bolina from Fiji. The Wolbachia ftsZ gene was amplified using the PCR primers ftsZf1 ( $5^{\prime}-$ GTT GTC GCA AAT ACC GAT GC-3') and ftsZr1 (5'CTT AAG TAA GCT GGT ATA TC-3') (Werren et al, 1995). The PCR primers wsp81f and wsp 691r (see above) were used to amplify the wsp gene (Zhou et al, 1998). In each case, PCR product was purified using Microcon-50 Micro concentrators (Amicon Ltd). Both strands were sequenced in totality direct from the PCR product using the PCR primers. Due to the greater size of the fts $Z$ gene, internal primers were designed and used for sequence analysis: ftsZ-IntR (5'-ATC GGC GAG TTG AAA TGC$\left.3^{\prime}\right)$ and ftsZ-IntF (5'-ATA TTG GCA TAA GAG GAG$\left.3^{\prime}\right)$. The $f t s Z$ and wsp sequences were manually aligned to previously determined Wolbachia sequences of these genes, and the phylogenetic affiliation of the $H$. bolina Wolbachia recorded.

\section{Antibiotic treatment}

Antibiotics (tetracycline or rifampicin) of known concentration were painted onto fresh I. batatus leaves and fed to different groups of fourth instar larvae. Both antibiotics have been previously demonstrated to cure insects infected with cytoplasmic bacteria (Stouthamer et al, 1990). Treatment was commenced when larvae reached fourth larval instar, and continued to pupation. A known amount of antibiotic was presented to larvae under each of seven different treatment regimes. The leaf area consumed per day for each treatment regime was recorded. This data, together with the concentration of antibiotic and the number of larvae in the experiment, was used to calculate the mean amount of antibiotic consumed by each larva (Table 1). Control groups from the same matrilines were fed on untreated plants. Progeny from females reared on each of the antibiotic regimes were tested for Wolbachia presence as previously described.

\section{EM analysis for infecting microorganisms}

Fresh F2 adult $H$. bolina females from all-female lines were dissected, and their ovaries removed. Following primary fixation in a $2 \%$ glutaraldehyde-based fixative and washing in $0.1 \mathrm{M}$ sodium cacodylate buffer, the ovarian tissue was post-fixed in $1 \%$ osmium tetraoxide in $0.1 \mathrm{M}$ sodium cacodylate buffer and refrigerated for $1 \mathrm{~h}$. The tissue was stained with $2 \%$ uranyl acetate then dehydrated in a series of graded alcohol before being embedded in Araldite resin. Following polymerisation at $60^{\circ} \mathrm{C}$ overnight, specimens were cut into 70-90 nm sections and examined in a Jeol 1010 transmission electron microscope at $80 \mathrm{~Kb}$.

\section{Prevalence}

Female $H$. bolina were collected from three island locations within the Fijian archipelago: Viti Levu, 
Table 1 Mean amount of antibiotic consumed by larvae in infected and uninfected lines, following different treatment regimes

\begin{tabular}{ccc}
\hline $\begin{array}{c}\text { Antibiotic } \\
\text { treatment } \\
\text { regime }\end{array}$ & Mean amount of antibiotic per larva $(\mathrm{mg})$ \\
\cline { 2 - 3 } & $\begin{array}{c}\text { Uninfected matrilines } \\
\text { (normal sex ratio) }\end{array}$ & $\begin{array}{c}\text { Infected matrilines } \\
\text { (all-female) }\end{array}$ \\
\hline 0.1\% Rifampicin & 0.040 & 0.064 \\
Once & $(20)$ & $(16)$ \\
0.1\% Rifampicin & 0.190 & 0.246 \\
Alternate days & $(20)$ & $(19)$ \\
1\% Rifampicin & 0.475 & 0.708 \\
Once & $(20)$ & $(16)$ \\
1\% Rifampicin & 1.440 & 1.974 \\
Every third day & $(20)$ & $(19)$ \\
1\% Tetracycline & 0.540 & 0.887 \\
Once & $(16)$ & $(10)$ \\
1\% Tetracycline & 2.443 & 2.417 \\
Alternate days & $(18)$ & $(10)$ \\
1\% Tetracycline & 8.43 & 4.07 \\
Every day & $(6)$ & $(8)$ \\
\hline
\end{tabular}

Numbers in brackets indicate the number of larvae subjected to the regime. Treatments were commenced at fourth instar and continued till pupation ( 8 to 10 days)

Taveuni and Wayalailai. The specimens were preserved in $95 \%$ ethanol immediately following death. DNA was extracted from each specimen and the supernatant used directly in PCR assay using the Wolbachia B-group specific wsp primers, 522r (5'-ACC AGC TTT TGC TTG ATA-3') and 81f (see above) (Zhou et al, 1998). The sequence of the wsp gene was obtained from a single infected individual from each island location to ensure the infection was the same.

\section{Results}

\section{Identification of male-killing lines}

The prevalence of the all-female trait was found to be $0.58 \%(n=12)$ among broods reared from wild females (binomial 95\% CI: lower 0.28, upper 0.85). The all-female trait showed matrilineal inheritance, reinforcing previous findings (Poulton, 1923; Clarke et al, 1975b) (Table 2). The adult sex ratio, in both the F1 and F2 generations, was not significantly different from 1:1 in the normal broods $\left(\chi^{2}=4.737 ; \mathrm{df}=2\right.$; NS (test for homogeneity between lines: $\left.\chi^{2}=0.79 ; \mathrm{df}=10 ; \mathrm{NS}\right)$ ). Males only occurred in the F1 generation in one all-female matriline, in a single brood, but even here there was a strong female bias.

The hatch rates of clutches of eggs from all-female matrilines are significantly lower than those from normal matrilines (Mann-Whitney $\mathrm{U}$ test: $\mathrm{n} 1=5 ; \mathrm{n} 2=7 ; P<$ 0.01). No instances of sibling egg cannibalism were recorded, even in cases where newly hatched larvae were confined with their siblings and with no alternative food source.

Association of Wolbachia with all-female trait

PCR analysis of the laboratory reared females revealed a correlation with the presence of Wolbachia and the allfemale trait. Template from all seven all-female matril- ines gave amplification products with wsp primers, whereas template from five normal sex ratio matrilines did not.

\section{Sequence analysis and phylogeny}

Sequence analysis of the wsp and ftsZ genes of the $H$. bolina Wolbachia revealed them to be identical in sequence to the male killing Wolbachia strain from the butterfly Acraea encedon in Tanzania (accession numbers: ftsZ, AJ307075; wsp, AJ307076). Thus the phylogenetic position of the male killing Wolbachia in H. bolina is the same as that of the Tanzanian A. encedon. A phylogeny showing how this male killing Wolbachia relates to other Wolbachia is given by Jiggins et al (2001a).

\section{Antibiotic treatments}

Neither the sex ratio bias nor the half-hatch rate observed in all-female matrilines were affected by treatment with antibiotics. In fact no effect from antibiotic treatment was observed in either all-female or control lines. This is surprising when it is considered that some of the adults that were bred consumed $2.85 \mathrm{mg}$ rifampicin, and others 8.23 $\mathrm{mg}$ tetracycline as larvae. PCR assay for the presence of Wolbachia, using template from F2 adult females who's infected mother had consumed antibiotics as a larva, revealed that the antibiotics had failed to cure the Wolbachia bacteria, as well as the all-female trait.

\section{EM analysis for infecting microorganisms}

Analysis of ovarian tissue from infected individuals revealed presence of double membraned prokaryotic cells approximately two microns long, each enclosed within a host vacuole (Figure 1). These prokaryotes were not present in uninfected strains. No eukaryotes were observed in either type of tissue.

\section{Prevalence}

Prevalence of the male-killer was assayed in three different areas of Fiji, as shown in Table 3. Chi-squared analysis rejects the null hypothesis of homogeneity between islands $\left(\chi^{2}=7.778, \mathrm{df}=2 ; P=0.02\right)$ indicating variation in prevalence of the male killing trait across the Fiji Islands.

\section{Discussion}

Correlation between the presence of Wolbachia and the all-female trait across different matrilines, as revealed by PCR assay, indicates that Wolbachia is the cause of malekilling in the butterfly $H$. bolina. Wolbachia bacteria represent one of the most widespread causal agents of embryonic male killing, being responsible for one third of reported cases to date. Knowing this, and given the frequency of Wolbachia in insects and other arthropods (Stouthamer et al, 1999) it is perhaps unsurprising to find that we are dealing with another Wolbachia male killer. These findings support the view that there will be many unreported cases of Wolbachia male-killing in the wild, and that male-killing will be a common phenotype within the clade Wolbachia (Jiggins et al, 2001b).

The result that a male-killing Wolbachia is responsible for all-female broods in $H$. bolina is further reinforced by the fact that the sequences of the wsp and ftsZ genes of this Wolbachia are identical to those in a known causal agent of male killing. The two host species $H$. bolina and 
Table 2 Hatch rates and sex ratios produced by wild (parental) female Hypolimnas bolina and in the subsequent F1 generation

\begin{tabular}{|c|c|c|c|c|c|c|}
\hline \multirow{2}{*}{$\begin{array}{l}\text { Matriline } \\
\text { number }\end{array}$} & \multicolumn{3}{|c|}{ Parental Females } & \multicolumn{3}{|c|}{ F1 Females } \\
\hline & $\begin{array}{c}\text { \% Hatch } \\
\text { (n) }\end{array}$ & $\begin{array}{c}\text { Male } \\
\text { progeny }\end{array}$ & $\begin{array}{l}\text { Female } \\
\text { progeny }\end{array}$ & $\begin{array}{c}\text { \% Hatch } \\
\text { (n) }\end{array}$ & $\begin{array}{c}\text { Male } \\
\text { progeny }\end{array}$ & $\begin{array}{c}\text { Female } \\
\text { progeny }\end{array}$ \\
\hline \multicolumn{7}{|c|}{ (a) All-female broods } \\
\hline \multirow[t]{3}{*}{1} & $\begin{array}{l}50.96 \\
(104)\end{array}$ & 0 & 37 & $\begin{array}{r}46.88 \\
(32)\end{array}$ & 0 & 12 \\
\hline & & & & $\begin{array}{l}48.15 \\
(189)\end{array}$ & 0 & 35 \\
\hline & & & & $\begin{array}{l}53.55 \\
(183)\end{array}$ & 0 & 53 \\
\hline 2 & $\begin{array}{r}48.48 \\
(33)\end{array}$ & 0 & 15 & & & \\
\hline \multirow[t]{2}{*}{3} & $\begin{array}{r}53.16 \\
(79)\end{array}$ & 5 & 33 & $\begin{array}{r}50.00 \\
(6)\end{array}$ & 0 & 2 \\
\hline & & & & $\begin{array}{l}49.40 \\
(336)\end{array}$ & 0 & 38 \\
\hline \multirow[t]{5}{*}{4} & $\begin{array}{l}41.22 \\
(148)\end{array}$ & 0 & 54 & $\begin{array}{r}45.61 \\
(57)\end{array}$ & 0 & 19 \\
\hline & & & & $\begin{array}{r}55.56 \\
(27)\end{array}$ & 0 & 12 \\
\hline & & & & $\begin{array}{r}44.44 \\
(9)\end{array}$ & 0 & 4 \\
\hline & & & & $\begin{array}{r}46.24 \\
(93)\end{array}$ & 0 & 23 \\
\hline & & & & $\begin{array}{r}40.91 \\
(22)\end{array}$ & 0 & 3 \\
\hline 5 & $\begin{array}{r}39.44 \\
(71)\end{array}$ & 0 & 16 & & & \\
\hline 6 & $\begin{array}{r}38.46 \\
(13)\end{array}$ & 0 & 5 & & & \\
\hline 7 & $\begin{array}{r}39.66 \\
(58)\end{array}$ & 0 & 40 & $\begin{array}{r}43.33 \\
(90)\end{array}$ & 0 & 24 \\
\hline & & & & $\begin{array}{r}45.45 \\
(33)\end{array}$ & 0 & 12 \\
\hline \multicolumn{2}{|c|}{ (b) Normal sex ratio broods } & & & $\begin{array}{r}51.02 \\
(49)\end{array}$ & 0 & 17 \\
\hline \multirow[t]{4}{*}{8} & $\begin{array}{l}88.89 \\
(341)\end{array}$ & 54 & 53 & $\begin{array}{r}100.00 \\
(33)\end{array}$ & 10 & 7 \\
\hline & & & & $\begin{array}{r}100.00 \\
(56)\end{array}$ & 11 & 7 \\
\hline & & & & $\begin{array}{r}97.47 \\
(79)\end{array}$ & 8 & 5 \\
\hline & & & & $\begin{array}{r}96.34 \\
(82)\end{array}$ & 6 & 9 \\
\hline \multirow[t]{2}{*}{9} & $\begin{array}{l}93.69 \\
(111)\end{array}$ & 38 & 33 & $\begin{array}{r}100.00 \\
(36)\end{array}$ & 8 & 4 \\
\hline & & & & $\begin{array}{r}100.00 \\
(3)\end{array}$ & 2 & 1 \\
\hline 10 & $\begin{array}{l}98.94 \\
(282)\end{array}$ & 13 & 11 & & & \\
\hline 11 & $\begin{array}{c}100.00 \\
(12)\end{array}$ & 3 & 5 & & & \\
\hline 12 & $\begin{array}{l}97.71 \\
(131)\end{array}$ & 18 & 20 & & & \\
\hline
\end{tabular}

A. encedon are only distantly related (they are in different tribes within the family Nymphalidae) but share an identical male killing Wolbachia, strongly implicating horizontal transmission of the male killing element. This suggests that certain Wolbachia strains specialise on certain host sex determination systems. In butterflies, the male is the homogametic sex, in contrast to the majority of other insects. Perhaps only particular strains of male killer are able to act on host systems of this type. More lepidopteran male killers need to be examined in order to verify this.

One notable result from this study is the failure of anti- 


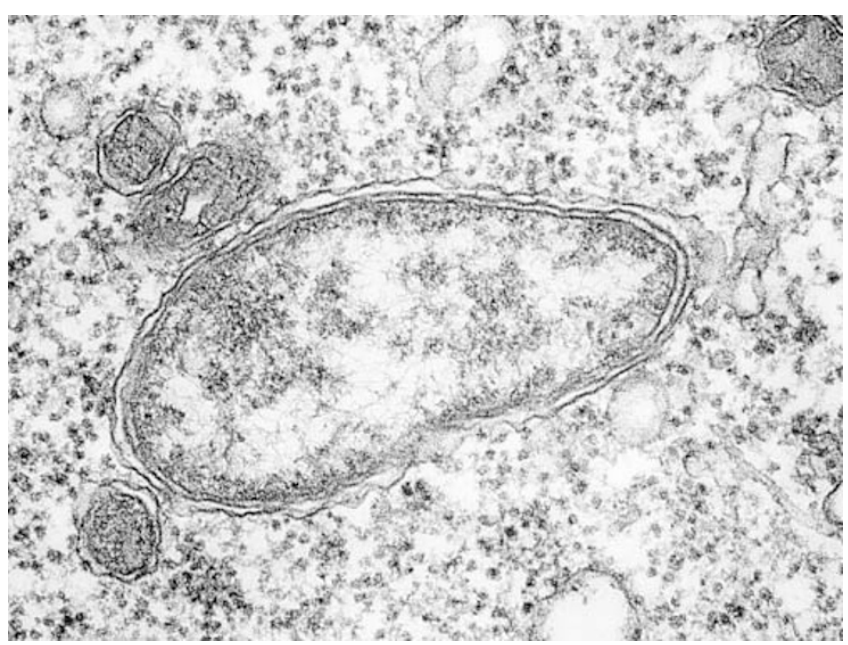

Figure 1 Transmission electron micrograph showing a prokaryotic cell enclosed in a vacuole, in ovarian tissue taken from an F2 female Hypolimnas bolina from an all-female line. (Original size: 2 microns).

Table 3 Percentage prevalence of Wolbachia male killer in Hypolimnas bolina females across different islands of Fiji

\begin{tabular}{lcc}
\hline Area of Fiji & $\begin{array}{c}\text { Prevalence } \\
(\%)\end{array}$ & $n$ \\
\hline Viti Levu Island & 58.82 & 34 \\
Wayalailai Island & 56 & 50 \\
Taveuni Island & 25 & 24 \\
\hline
\end{tabular}

biotics to cure the all-female trait. This does not rule out Wolbachia as the cause of male killing in H. bolina as antibiotics did not cure the Wolbachia infection either. There are many examples of cases in which just a single treatment with antibiotic will cure infected arthropods of sexratio distorting bacteria (Stouthamer et al, 1990). Why this should not be the case in $H$. bolina remains a mystery for further investigation. Potential explanations of the cause of failure of two different antibiotics to cure both the Wolbachia infection and the all-female trait in $H$. bolina are that either the Wolbachia are antibiotic-resistant, or that the host did not sequester the antibiotics. Antibioticresistant Wolbachia would be a very useful tool for manipulation of this bacterium, and thus the investigation of the lack of response of the trait and bacterium to antibiotics should be carried further. However, there are huge implications on other Wolbachia/host systems if these bacteria can develop antibiotic resistance: Wolbachia is thought to play an essential role in the biology and metabolism of filarial worms that cause diseases such as river blindness in humans. Elimination of Wolbachia using tetracycline will also kill the adult nematodes (Langworthy et al, 2000). The ability of Wolbachia to evolve antibiotic resistance, as suggested in this paper, may lower the long-term utility of antibiotics in drug treatment of filiariasis.

Wolbachia prevalence is well understood in theory, but not in practice. Data from Clarke et al (1975b) indicates a high degree of variation in prevalence of the male-killer in $H$. bolina across different populations. In this study, prevalence is seen to vary across the different islands of
Fiji. The cause of this variation will be an important topic for future work, allowing insight into the factors producing differences in prevalence within a single host-parasite interaction. It should be possible to examine genetic and ecological characteristics in different populations to see if there is any evidence for the presence of resistance genes on certain islands, or if any correlates with life history traits and male-killer prevalence exist in this species. Notably, H. bolina lays eggs in clutches of 10-12 eggs in the Fiji Islands (personal observation) whereas in Australia (where Clarke found no evidence for the presence of a male killer) the species lays eggs singly or in pairs. Given the importance of sibling competition in the spread of male-killers (Hurst and Majerus, 1993), further investigation into this phenomenon across a range of populations may give an insight into possible causes and maintenance of a male killing cytoplasmic factor within a host population.

\section{Acknowledgements}

None of the fieldwork could have been carried out without the facilities provided by the Fiji Ministry of Forestry, and technical support from Eminoni Rokitovitovi, Eliki Senivasa Sigarugurugu, Peni Salabogi Cawani and Rashmi Prakash Sharma. Wilco Liebregts was invaluable in setting up this research. We wish to acknowledge support from the BBSRC (Studentship to ED, David Phillips Fellowship to GH). Thanks also to two anonymous reviewers for their comments.

\section{References}

Brunton CFA, Hurst GDD (1998). Mitochondrial DNA phylogeny of brimstone butterflies (genus Gonepteryx) from the Canary Islands and Madeira. Bio J Linn Soc 63: 69-79.

Clarke C, Johnston G, Johnston B (1983). All-female broods in Hypolimnas bolina (L) - A re-survey of west Fiji after 60 years. Bio J Linn Soc 19: 221-235.

Clarke C, Sheppard PM (1975a). The genetics of the mimetic butterfly Hypolimnas bolina. Phil Trans R Soc Lond 272: 229-265.

Clarke C, Sheppard PM, Scali V (1975b). All female broods in the butterly Hypolimnas bolina. Proc R Soc Lond B 189: 29-37.

Fialho RF, Stevens L (2000). Male-killing Wolbachia in a flour bettle. Proc R Soc Lond B 267: 1469-1473.

Hurst GDD, Bandi C, Sacchi L, Cochrane AG, Bertrand D, Karaca I et al (1999a). Adonia variegata (Coleoptera: Coccinellidae) bears maternally inherited Flavobacteria that kill males only. Parasitology 118: 125-134.

Hurst GDD, Hurst LD, Majerus MEN (1997). Cytoplasmic sex ratio distorters. In: $\mathrm{O}^{\prime}$ Neill S, Hoffmann AA, Werren JH (eds) Influential Passengers, Oxford University Press: New York, pp $125-154$.

Hurst GDD, Jiggins FM, Schulenburg JHG vd, Bertrand D, West SA, Goriacheva II et al (1999c). Male-killing Wolbachia in two species of insect. Proc $R$ Soc Lond B 266: 735-740.

Hurst GDD, Johnson AP, Schulenburg JHG vd, Fuyama Y (2000). Male-killing Wolbachia in Drosophila: a temperature sensitive trait with a threshold bacterial density. Genetics 156: 699-709.

Hurst GDD, Schulenburg JHG vd, Majerus TMO, Bertrand D, Zakharov IA, Baungaard J et al (1999b). Invasion of one insect speices, Adalia bipunctata, by two different male-killing bacteria. Insect Mol Biol 8: 133-139.

Hurst GDD, Majerus MEN (1993). Why do maternally inherited microorganisms kill males? Heredity 71: 81-95.

Jiggins FM, Bentley JK, Majerus MEN, Hurst GDD (2001b). How many species are infected with Wolbachia? Cryptic sex ratio 
distorters revealed to be common by intensive sampling. Proc $R$ Soc Lond B 268: 1123-1126.

Jiggins FM, Hurst GDD, Schulenburg JHG vd, Majerus MEN (2001a). Two male-killing Wolbachia strains coexist in a population of the butterfly Acraea encedon. Heredity 86: 161-166.

Jiggins FM, Hurst GDD, Dolman CE, Majerus MEN (2000b). High prevalence male-killing Wolbachia in the butterfly Acraea encedana. J Evol Biol 13: 495-501.

Jiggins FM, Hurst GDD, Jiggins CD, Schulenburg JHG vd, Majerus MEN (2000a). The ecology of male-killer hosts: the butterfly Danaus chrysippus is infected by a male-killing Spiroplasma bacerium. Parasitology 20: 439-446.

Langworthy NG, Renz A, Mackenstedt U, Henkle-Duhrsen K, Bronsvoort MBD, Tanya VN et al (2000). Macrofilaricidal activity of tetracycline against the filarial nematode Onchocerca ochengi: elimination of Wolbachia precedes worm death and suggests a dependent relationship. Proc R Soc Lond B 267: 1063-1069.

Poulton EB (1923). All female families of Hypolimnas bolina, bred in Fiji by HW Simmonds. Proc R Ent Soc Lond 1923: 9-12.

Poulton EB (1927). Sex-ratio of Hypolimnas bolina, L., in Viti Levu, Fiji. Proc R Ent Soc Lond 2: 5-10.

Poulton EB (1928). Mr H.W. Simmonds' conclusion that allfemale producing females form a persistent strain in Suva. Proc R Soc Lond 3: 43-44.

Rigaud T (1997). Inherited microorganisms and sex determination of arthropod hosts. In: O'Neil S, Hoffmann AA, Werren JH (eds) Influential Passengers, Oxford University Press: New York, pp 81-101.

Schulenburg JHGvd, Majerus TMO, Dorzhu CM, Zakharov IA, Hurst GDD, Majerus MEN (2000). Evolution of male-killing Spiroplasma (Procaryotae: Mollicutes) inferred from ribosomal spacer sequences. J Gen Appl Microbiol 46: 95-98.

Simmonds HW (1926). Sex ratio of Hypolimnas bolina in Viti Levu, Fiji. Proc R Ent Soc Lond 1: 29-32.

Stouthamer R (1997). Wolbachia-induced parthenogenesis. In: O'Neill S, Hoffmann AA, Werren JH (eds) Influential Passengers, Oxford University Press: New York, pp 102-124.

Stouthamer R, Breeuwer JAJ, Hurst GDD (1999). Wolbachia pipientis: Microbial manipulator of arthropod reproduction. Ann Rev Microbiol 53: 71-102.

Stouthamer R, Hurst GDD, Breeuwer JAJ (2001). Sex ratio distorters. In: Hardy ICW (ed) The Sex Ratio Handbook, Cambridge University Press: Cambridge, in press.

Stouthamer R, Luck RF, Hamilton WD (1990). Antibiotics cause parthenogenetic Trichogramma (Hymenoptera/Trichogrammatidae) to revert to sex. Proc Natl Acad Sci USA 87: 2424-2427.

Vane-Wright RI, Ackery PR, Smiles RL (1977). The polymorphism, mimicry and host plant relationships of Hypolimnas butterflies. Bio J Linn Soc 9: 285-297.

Werren JH, Hurst GDD, Zhang W, Breeuwer JAJ, Stouthamer R, Majerus MEN (1994). Rickettsial relative associated with male killing in the ladybird beetle (Adalia bipunctata). J Bacteriol 176: 388-394.

Werren JH, Skinner SW, Huger AM (1986). Male-killing bacteria in a parasitic wasp. Science 231: 990-992.

Werren JH, Zhang W, Guo LR (1995). Evolution and phylogeny of Wolbachia - reproductive parasites of arthropods. Proc $R$ Soc Lond B 261: 55-63.

Williamson DL, Poulson DF (1979). Sex ratio organisms (spiroplasmas) of Drosophila. In: Whitcomb RF, Tully JF (eds) The Mycoplasmas, Academic Press: New York. pp 175-208.

Zhou WG, Rousset F, Oneill S (1998). Phylogeny and PCR-based classification of Wolbachia strains using wsp gene sequences. Proc R Soc Lond B 265: 509-515. 